\title{
Dapsone compliance in North-east India
}

\author{
ROSALYN A DAVIES \& YIN YEUN NG \\ Middlesex Hospital Medical School, \\ Cleveland Street, London W1 P 7PN \\ Received for publication 5 February 1980
}

Summary The dapsone/creatinine ratios of urine samples collected from out-patients attending a mission hospital clinic in North-east India indicated that only about a half of the patients had ingested their prescribed dapsone within the previous $24 \mathrm{~h}$.

\section{Introduction}

Previous investigations undertaken in various parts of Africa and Asia have shown that leprosy patients often self-administer their prescribed dapsone treatment irregularly. ${ }^{1-5}$ This report describes a study of dapsone compliance among patients being treated by the Leprosy Mission Hospital, Muzaffarpur, in North-east India.

\section{Methods}

Urine samples were collected from male staff members of the hospital who were not taking dapsone, from male in-patients 24-h after their previous daily supervised dose of $100 \mathrm{mg}$ dapsone and from male out-patients at the time of their visit to collect a further stock of $100 \mathrm{mg}$ dapsone tablets for daily selfadministration. A small crystal of thymol was then added to each urine sample and the samples stored without refrigeration at ambient temperatures of $75^{\circ}$ to $100^{\circ} \mathrm{F}$ for 4 months until analysis in London. Urinary concentrations of diazotisable compounds (as dapsone equivalents) were determined by a modification of the Bratton and Marshall procedure, creatinine concentrations were determined using the alkaline picrate method, and 'dapsone/creatinine' ratios then calculated. ${ }^{6}$ 


\section{Results and discussion}

In about a fifth of the samples (14 out of 72) abnormally low concentrations of creatinine (less than $0.1 \mathrm{mg} / \mathrm{ml}$ ) were encountered despite seemingly normal levels of diazotisable compounds. It was surmized that in these samples creatinine must have been bacterially degraded, although the reason why the thymol had apparently failed to act as a preservative is not understood. The creatinine concentrations of the remaining 58 samples appeared to be normal (range 0.16 to $1.84 \mathrm{mg} / \mathrm{ml}$, mean $0.53 \mathrm{mg} / \mathrm{ml}$ ). Although the numbers of control samples were small, the results obtained were in accord with those obtained in previous studies from Addis Ababa in Ethiopia ${ }^{1}$ and from Dichpalli in India. ${ }^{7}$ Thus the mean dapsone/creatinine ratios $(\mu \mathrm{g} / \mathrm{mg})$ averaged 9 for the 5 controls not on dapsone as compared with 7 from Addis Ababa and Dichpalli, while those from the supervised controls being treated with $100 \mathrm{mg}$ dapsone a day averaged 92 as compared with 80 from Addis Ababa and 102 from Dichpalli.

The results obtained from the 44 satisfactory urine samples collected from the out-patients were interpreted in the light of those from the treated and untreated controls in Muzaffarpur, Dichpalli and Addis Ababa. Dapsone/ creatinine ratios of greater than 50, indicating that a dose of $100 \mathrm{mg}$ dapsone had been taken within the $24 \mathrm{~h}$ prior to the clinic, were found in only about a half of the urine samples. Furthermore 11 of the urine samples had dapsone/ creatinine ratios of less than 16.8 , the highest value for the untreated controls, indicating that about a quarter of the patients had probably not taken their prescribed treatment for at least the previous 3-4 days. The results of this small study therefore support the findings of previous investigations indicating that poor dapsone compliance is probably very widespread. It was also apparent that some patients failed to appreciate that their running out of dapsone tablets was often a consequence of missed out-patient clinic appointments. Hence the importance of educating patients about the dangers of irregular treatment.

\section{Acknowledgements}

We would like to thank Dr GA Ellard for his invaluable help in the analysis and interpretation of the data; Dr Margaret Owen and staff at the Leprosy Mission Hospital, Muzaffarpur, for their helpful advice and co-operation; and Professor Hobbiger of the Middlesex Hospital, London, for his advice in planning this investigation. We should also like to express our gratitude to the Leprosy Mission and the Medical Research Council who afforded us this opportunity to carry out our study. 
1 Low SJM, Pearson JMH. Do leprosy patients take dapsone regularly? Lepr Rev, 1974, 45, $218-23$.

2 Ellard GA, Gammon PT, Harris JM. The application of urine tests to monitor the regularity of dapsone self-administration. Lepr Rev, 1974, 45, 224-34.

3 Huikeshoven HC, Honhoff C, Van Eys GJJM, Anten IGF, Mayer JMA, Van Helden HPT. Weekly self-medication of leprosy patients monitored by DDS/creatinine ratios in urines. Lepr Rev, 1976, 47, 201-9.

4 Balakrishan S. Monitoring self-administration of dapsone by patients. Lepr India, 1977, 49, 364-70.

5 Hagan KJ, Smith SE, Gyi KM, Lwin MM, Myiang YY, Oo KM. The reliability of selfadministration of dapsone by leprosy patients in Burma. Lepr Rev, 1979, 50, 201-11.

6 Ellard GA, Gammon PT, Helmy HS, Rees RJW. Urine tests to monitor the selfadministration of dapsone by leprosy patients. Amer J trop Med Hyg, 1974, 23, 464-70.

7 Ellard GA. Personal communication. 